\title{
Factors Influencing Predation of the Waterbugs Sphaerodema annulatum (Fab.) and S. rusticum (Fab.) on the Disease Transmitting Snail Lymnaea (Radix) luteola (Lamarck)
}

\author{
JK Roy, SK Raut
} Ecology and Ethology Laboratory, Department of Zoology, University of Calcutta, 35 Ballygunge Circular Road,
Calcutta 700019 , India

Variations in the rate of predation of the waterbugs Sphaerodema annulatum and $\mathrm{S}$. rusticum on the snails Lymnaea (Radix) luteola have been noted in respect to the morphs of the waterbugs, size of the prey individuals, densities of prey and predators, temperature and surface area of the waterbody concerned and the seasons. Consumption rate was highest (7.2 and 2.2 individuals per day per individual of $\mathrm{S}$. annulatum and $\mathrm{S}$. rusticum, respectively) in prereproductive ages of the waterbugs. This was followed by a gradual decline with the increase in age of the predators. The consumption rate was gradually higher with the increase of temperature from $20^{\circ} \mathrm{C}$ to $35^{\circ} \mathrm{C}$. The bugs failed to survive beyond 35 days at $35^{\circ} \mathrm{C}$. Though the bugs prey upon the snails of all sizes preference for $6.5 \times 4.5 \mathrm{~mm}$ to $8 \times 5 \mathrm{~mm}$ individuals by S. annulatum and for $5 \times 3 \mathrm{~mm}$ to $6.5 \times$ $4.5 \mathrm{~mm}$ individuals by $\mathrm{S}$. rusticum is established. The waterbugs, irrespective of species, consumed the snail individuals belonged to $3 \times 2-4 \times 3 \mathrm{~mm}$ size group maximum when supplied separately. The rate of predation gradually declined with the rise of predalor's density irrespective of waterbug species.

Predation rate increased with increasing prey density. This was level off when the prey snails were 1100 and 700 in number for $\mathrm{S}$. annulatum and S. rusticum respectively. An adult S. annulatum and S. rusticum consumed 5.04, 3.7, 1.43 and 3.36, 2.49, 1.04 snails per day respectively in summer, monsoon and winter.

Key words: waterbug - snail - predation - India

Considering the severity of snail-borne diseases in man and his domestic animals (Chatterjee 1952, Thomas 1973, Malek \& Cheng 1974) various attempts are being made to keep the density of the snail-host population below the effective level. In such attempts, though a good number of molluscicides are giving encouraging results (Levine 1970, Chu 1978, Godan 1983, Abebe 1991) we hesitate to recommend use of the same due to evolved environmental hazards. Obviously, natural enemies, especially the predators of snail-host species are taken into account. The biological agents involved with the reduction of snail populations are leeches (Chernin et al. 1956, Wright 1968, Raut \& Nandi 1985), ostracods (Lo 1967), crayfishes (Deschiens \& Lamy 1955), crabs (Deschiens et al. 1955), sciomyzid flies (Berg 1953, 1964), coleopterans (Maillard 1971), waterbugs (Somasundarao 1963, Voelker 1966, 1968, Hairston et al. 1975, Raut et al. 1988, Raut \& Saha 1988, 1989, Saha \& Raut 1991), and snails (Chernin et al. 1956, Radke et al. 1961, Demian \& Lutfy 1966, Ruiz-

Received I March 1993

Accepted 14 January 1994
Tiben et al. 1969, Jobin et al. 1970). Of these, waterbugs are considered most effective agents. Based on Voelker's (1968) findings the World Health Organization recommended field trials of the waterbugs Limnogeton fieberi Mayr. for controlling the snails Biomphalaria glabrata (Say) and Physella acuta Draparnaud (Hairston et al. 1975).

In India, occurrence of the waterbugs Sphaerodema annulatum (Fab.) and S. rusticum (Fab.) is well established. They feed voraciously on the individuals of the medically important snail species Lymnaea (Radix) luteola (Lamarck). They may well be employed in controlling these snails. Since successful biological control depends on the selection of a natural enemy having high degree of host specificity or preference, a good reproductive capacity relative to the host, and good adaptation to a wide range of environmental conditions (DeBach 1974) and also on the trends of population dynamics of both the natural enemy and the pest, and on realistic quantitative assessments of the impact of the natural enemy on pest populations (Bay et al. 1976) it is essential to have data on these aspects of the concerned species before consider- 
ing the same as biological control agents. Keeping all these facts in mind and taking into consideration the results of earlier studies (Raut 1981, 1982, 1986, 1988, 1989, Raut \& Ghosh 1985, Raut \& Nandi 1985, Raut et al. 1988, Raut \& Saha 1988, 1989, Saha \& Raut 1991), an attempt was made to study the effectiveness of the waterbugs $S$. annulatum and $S$. rusticum in controlling the snails Lymnaea (Radix) luteola under varying ecological conditions. As in nature, the predation is continued by the morphs of two species of waterbugs simultaneously, on the preysnails of different sizes in different seasons, at a varying surface area of the water body having different depths and temperatures the role of these parameters in influencing the predation rate could not be rulled out. And, as such, all these factors have taken into account in the present programme of experimental studies under laboratory. The results of such studies would enable us to formulate the biological control programme in a more effective way.

\section{MATERLALS AND METHODS}

To meet up the requirement of waterbugs ( $S$. annulatum and $S$. musticum) and snails [Lymnaea (Radix) luteola] for experimental studies, they were reared in aquaria $(60 \times 20 \times 45 \mathrm{~cm}$ in size) under laboratory conditions following the methods described by Raut \& Saha (1989). As per programme the following experiments were designed to note the effect of certain factors on the rate of predation of the waterbugs concerned.

Experiment 1 : age of the waterbugs - In aquaria $(60 \times 25 \times 45 \mathrm{~cm})$ five zero-day old adult morph were regularly supplied with 100 snails throughout the life span.

Experiment II: water temperature - Ten zeroday old individuals of each morph of waterbugs were constantly supplied with 200 snails at 20 , $25,30,35^{\circ} \mathrm{C}$ constant temperatures maintained in B.O.D. chambers and at room temperatures $\left(17.5-32.5^{\circ} \mathrm{C}\right)$ throughout the duration of morphs. Plastic containers $(22 \mathrm{~cm}$ in diameter and 8 $\mathrm{cm}$ in height) containing 1.51 water were used.

Experiment III: prey (snail) size - In plastic containers (each $22 \times 8 \mathrm{~cm}$ in size containing 21 pond water) five waterbugs of prereproductive age group were regularly supplied with 100 snails of $\mathrm{G}_{1}(3 \times 2-4 \times 3 \mathrm{~mm}), \mathrm{G}_{2}(5 \times 3-6.5 \times 4.5 \mathrm{~mm})$, $\mathrm{G}_{3}(6.5 \times 4.5-8 \times 5 \mathrm{~mm})$ and $\mathrm{G}_{4}(12 \times 7-14 \times 9$ $\mathrm{mm}$ ) size groups, in equal proportion for a period of seven days.

Experiment $I V$ : height of water column Fifteen adult waterbugs of same age were regularly supplied with 200 snails in aquaria $(58 \mathrm{x}$ $28 \times 32 \mathrm{~cm}$ ) contained water up to 10,20 and
$30 \mathrm{~cm}$ of the height for a period of seven days.

Experiment $V$ : predator density - Five, 10 , 15 and 20 adult waterbugs of same age were supplied with 200 snails regularly for a period of seven days at room temperatures $\left(26-28^{\circ} \mathrm{C}\right)$ in plastic containers $(23 \times 12 \mathrm{~cm})$, each containing 31 water.

Experiment VI: prey density - Ten adult waterbugs were supplied with $100,200,300$ and so on, snail individuals in aquaria $(60 \times 25 \times 45$ $\mathrm{cm}$ ), each containing water up to $25 \mathrm{~cm}$ of the height, until the threshold level of predation was determined, for a period of seven days.

Experiment VII: surface area - Five adult waterbugs were supplied with 100 snails in plastic containers having 594, 1188 and $2376 \mathrm{~cm}^{2}$ water surface area for a period of seven days at room temperatures $\left(27-28{ }^{\circ} \mathrm{C}\right)$.

Experiment VIII: season - In Calcutta, India, three seasons viz. summer, monsoon and winter are well marked. Five individuals of each morph of waterbugs were supplied with 100 snails in plastic containers $(22 \times 7 \mathrm{~cm})$ throughout the duration of larval morphs, and for 53, 55 and 59 days in these seasons respectively, in case of adult morph.

All the above mentioned experiments were carried out separately in respect to waterbug species. The waterbugs, in all cases were of same age and almost equally healthy. The supplied snails were of preferred size group ( $8 \times 5-9 \times 5.5$ $\mathrm{mm}$ ). A strict hygienic condition was maintained throughout by changing water of the container, by removing dead waterbug and snail individuals, if any, and also by removing the empty shells of the snails consumed by the bugs regularly.

Data collected on every $24 \mathrm{hr}$ period in each experiment were analyzed and the mean was calculated. The value given after plus/minus indicates S.E. For statistical analysis, Pielou (1977) and Goon et al. (1976) were consulted.

\section{RESULTS}

The results are described in the following paragraphs as regards to experiments done.

Experiment I: the individuals belonged to $S$. annulatum and $S$. rusticum survived for 269-342 and 253-306 days, respectively. The rate of predation varied with the age of the waterbugs. On an average the five individuals belonged to $S$. annulatum and $S$. rusticum consumed $36.0 \pm$ $2.08,26.18 \pm 0.43$ and $14.42 \pm 1.03$, and 11.0 $\pm 1.18,8.44 \pm 0.20$ and $7.47 \pm 0.64$ snail individuals per day, respectively.

Experiment II: the morphs of $S$. annulatum and $S$. rusticum consumed a varying number of 


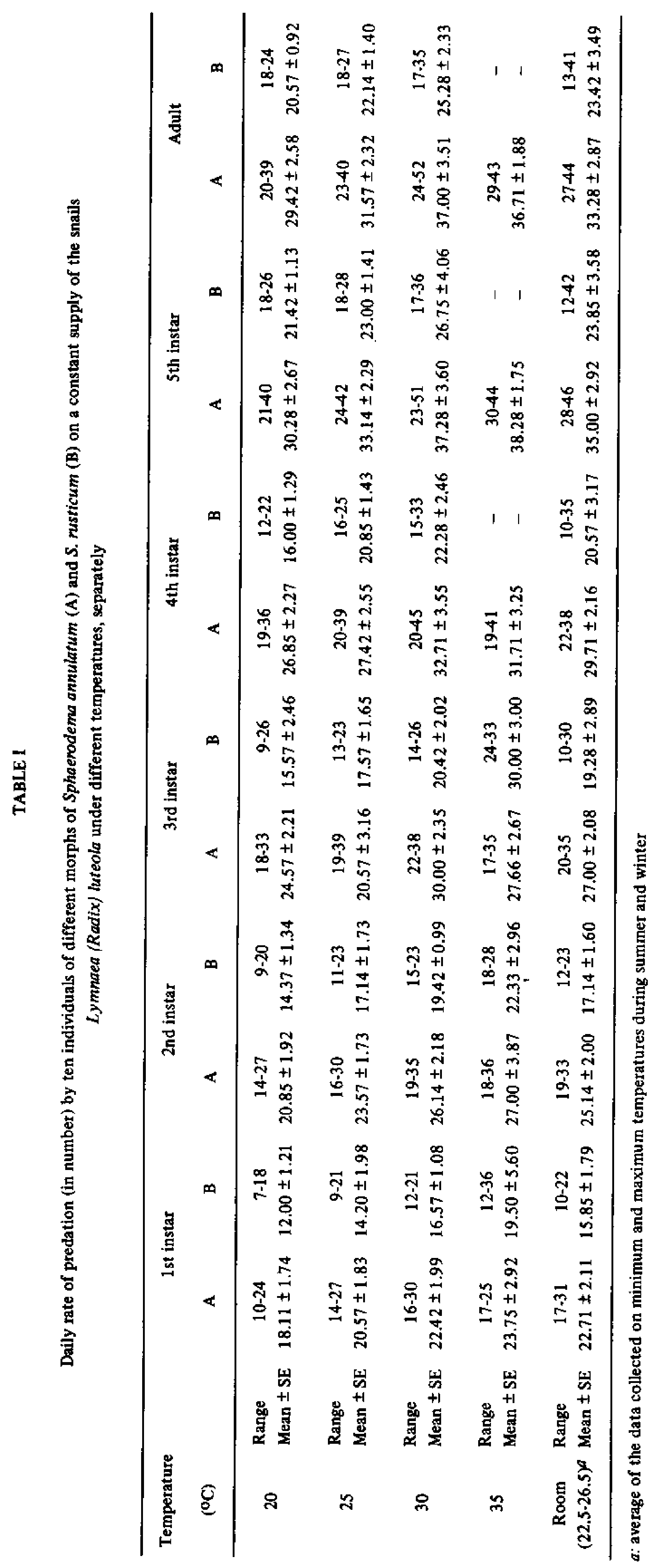


L. (R.) luteola in respect to temperature (Table I). The consumption rate was gradually higher from first instar larva to fifth instar larva irrespective of temperature grades.

Experiment III: the waterbugs consumed the snails of all the four size groups but the rate of consumption varied with the size of the snails supplied. Irrespective of waterbug species, the snail individuals belonged to $G_{1}$ size group were most preferred while individuals belonged to $G_{2}$, $G_{3}$ and $G_{4}$ size groups were next in order of consumption rate (Table II) when supplied separately. Considering the rates of predation by $S$. annulatum (A) and $S$. rusticum (R) the order of preference could be arranged in the following way:

$\mathrm{G}_{2} \mathrm{R}-\mathrm{G}_{1} \mathrm{R}-\mathrm{G}_{3} \mathrm{~A}-\mathrm{G}_{3} \mathrm{R}-\mathrm{G}_{4} \mathrm{R}-\mathrm{G}_{4} \mathrm{~A}-\mathrm{G}_{2} \mathrm{~A}-\mathrm{G}_{1} \mathrm{~A}$ $-\mathrm{G}_{4} \mathrm{R}$.

Experiment $I V$ : the selected 15 adult $S$. annulatum and $S$. rusticum consumed more or less same number of snail individuals in respect to the height of the water column. On an average $41.71 \pm 3.68,40.57 \pm 3.51$ and $39.28 \pm 3.57$ and $32.28 \pm 2.94,31.28 \pm 2.28$ and $30.28 \pm 2.9$ snails were consumed per day at 10,20 , and 30 $\mathrm{cm}$ height of the water column by the 15 individuals of $S$. annulatum and $S$. rusticum respectively.

\section{TABLE Il}

Daily rate of predation (range and mean \pm S.E. in number) by five (adult) Sphaerodema annulatum and $S$. rusticum on a constant supply of the snails Lymnaea (Radix) luteola of different sizes, separately

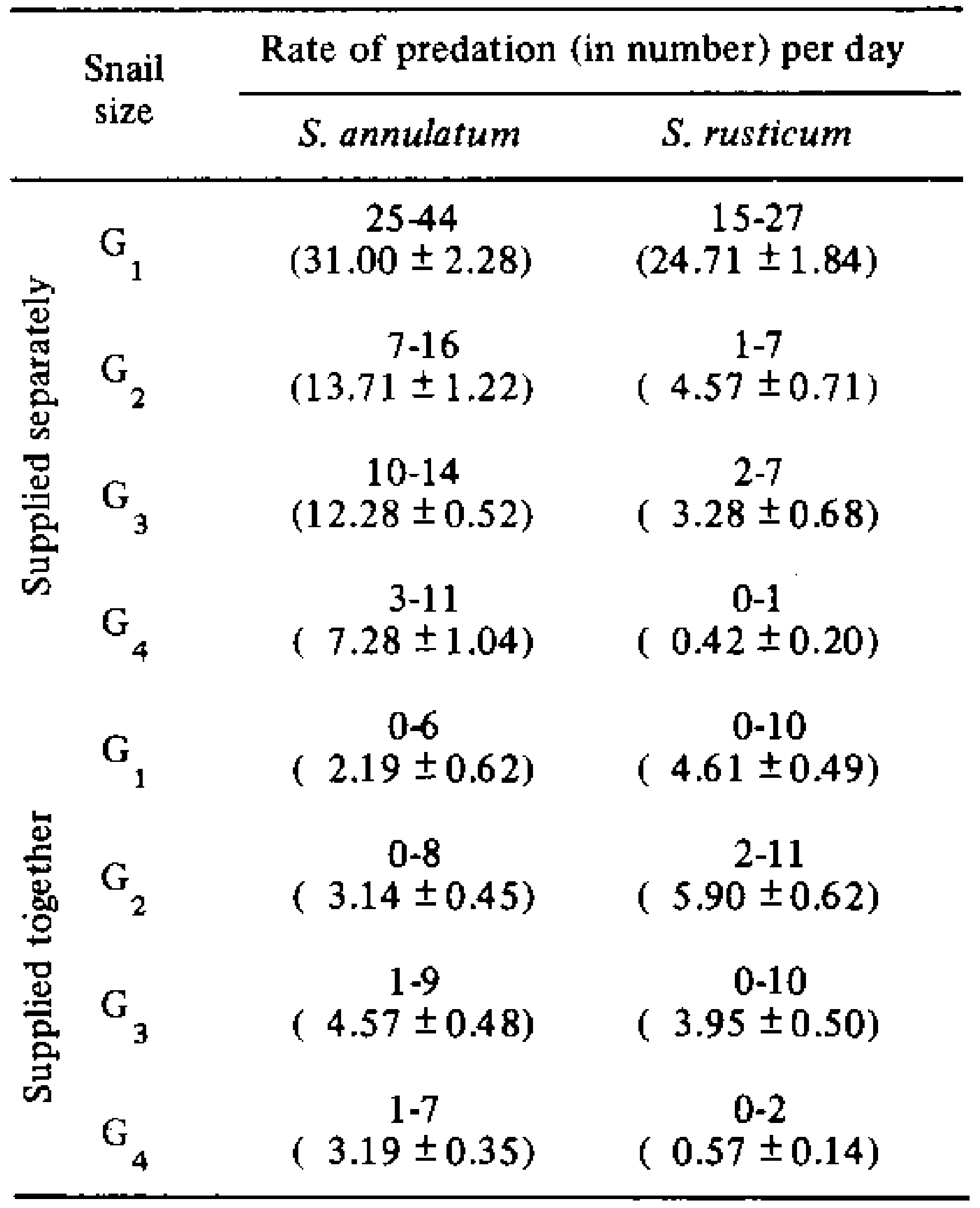

Experiment $V:$ an increased rate of predation has been noted in respect to increased predator density from 5 to 20 . The selected $5,10,15$, and 20 individuals belonged to $S$. annulatum consumed on an average, $13.00 \pm 0.72,23.57 \pm 1.7$, $36.14 \pm 1.92$, and $42.71 \pm 2.83$ snail individuals per day. Under similar situations same number of $S$. rusticum consumed $8.00 \pm 0.60,15.00 \pm 1.77$, $19.55 \pm 0.55$ and $26.85 \pm 1.62$ snail individuals daily. Figs $1 \mathrm{a}$ and $\mathrm{b}$ represent the rate of prey consumption per predator individual per day for a period of one week, separately, specieswise. It is clear that the rate of predation decreased when predator densities were 5 to 10 respectively but at such densities the predation rate became stable by the week end. At predator densities 15 and 20 respectively the rate of predation remained more or less stable throughout the week in case of $S$. annulatum (Fig. 1a). But, in case of $S$. rusticum (Fig. 1b) the pattern of prey consumption per predator increased to some extent over the stable rate by the end of the week when the predatordensities were 5 and 10 respectively. Whereas, when predator densities were 15 and 20 the rate of predation remained stable or parallel to the day axis throughout the week.

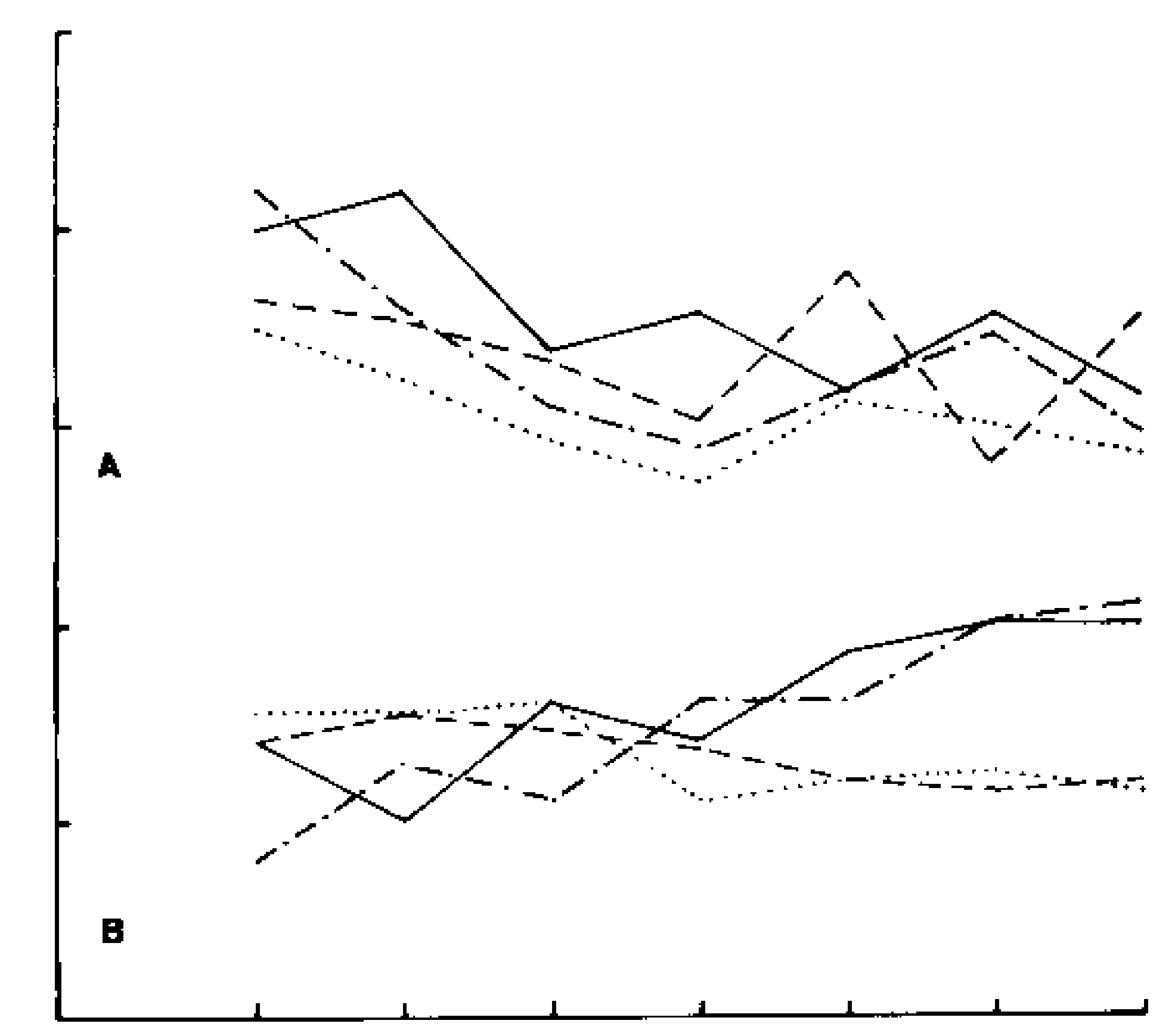

Impact of predator density (- $5,--.--10,-----15, \ldots \ldots$. 20 ) on the rate of predation. The number of prey snails was kept constant (200) in all experiments. Predators: A Sphaerodema annulatum B - Sphaerodema rusticum.

Experiment VI: the predation rate in waterbugs varied with the densities of prey-snail individuals (Table III). A gradual increase in the rate of predation with the increase in density of the prey-snail has been noted up to a certain level of snail density. The rate of predation was highest at 1100 snail density level in $S$. annulatum and at 700 snail density level in $S$. rusticum (Table III). 
TABLE III

Daily rate of predation (range and mean \pm S.E. in number) by ten adult Sphaerodema annulatum and S. rusticum on a constant supply of Lymnaea (Radix) luteola in different numbers for a period of seven days, separately in respect to waterbug species

\begin{tabular}{|c|c|c|}
\hline \multirow{2}{*}{$\begin{array}{c}\text { Snail } \\
\text { (in number) }\end{array}$} & \multicolumn{2}{|c|}{ Rate of predation (in number) per đay } \\
\hline & S. annulatum & S. rusticum \\
\hline 100 & $\begin{array}{c}22-59 \\
(39.00 \pm 5.50)\end{array}$ & $\begin{array}{c}8-17 \\
(11.85 \pm 1.33)\end{array}$ \\
\hline 200 & $\begin{array}{c}26-69 \\
(46.42 \pm 5.80)\end{array}$ & $\begin{array}{c}12-18 \\
(15.28 \pm 1.01)\end{array}$ \\
\hline 300 & $\begin{array}{c}27-71 \\
(50.71 \pm 6.24)\end{array}$ & $\begin{array}{c}15-24 \\
(18.71 \pm 1.26)\end{array}$ \\
\hline 400 & $\begin{array}{c}34-94 \\
(58.14 \pm 7.06)\end{array}$ & $\begin{array}{c}19-29 \\
(23.28 \pm 1.76)\end{array}$ \\
\hline 500 & $\begin{array}{c}30-85 \\
(65.71 \pm 7.20)\end{array}$ & $\begin{array}{c}28-36 \\
(34.42 \pm 1.28)\end{array}$ \\
\hline 600 & $\begin{array}{c}46-97 \\
(71.28 \pm 8.06)\end{array}$ & $\begin{array}{c}3244 \\
(38.00 \pm 1.38)\end{array}$ \\
\hline 700 & $\begin{array}{c}50-100 \\
(78.42 \pm 6.37)\end{array}$ & $\begin{array}{c}26-55 \\
(38.57 \pm 3.35)\end{array}$ \\
\hline 800 & $\begin{array}{c}49-102 \\
(81.42 \pm 6.80)\end{array}$ & $\begin{array}{c}32-48^{a} \\
(38.14 \pm 2.26)\end{array}$ \\
\hline 900 & $\begin{array}{c}53-104 \\
(84.57 \pm 6.52)\end{array}$ & - \\
\hline 1000 & $\begin{array}{c}60-112 \\
(89.71 \pm 6.96)\end{array}$ & - \\
\hline 1100 & $\begin{array}{c}62-110 \\
(90.14 \pm 6.42)\end{array}$ & - \\
\hline 1200 & $\begin{array}{c}61-108 \\
(89.14 \pm 6.43)\end{array}$ & - \\
\hline
\end{tabular}

a: experiment discontinued afterwards.

Experiment VII: the five adult $S$. annulatum and $S$. rusticum consumed, on an average 42.85 $\pm 4.83,35.42 \pm 3.62$ and $27.57 \pm 3.16$ and 27.00 $\pm 2.08,18.71 \pm 1.82$ and $13.85 \pm 1.12$ individuals of $L$. (R.) luteola per day at 594, 1188 and $2376 \mathrm{~cm}^{2}$ surface area of water respectively.

Experiment VIII: a marked variation in the rate of predation in respect to seasons have been noted in all experiments conducted with different morphs of $S$. annulatum and $S$, rusticum (Table IV).

Statistical analysis of the data clearly revealed that the age of the water-bugs has a significant effect on predation. It is also evident that the age and species of waterbug interact to have a
TABLE IV

Daily rate of predation (range and mean \pm S.E. in number) by five individuals of different morphs of Sphaerodema annulatum and $S$. rusticum on a constant supply of the snails Lymnaea (Radix) luteola in different seasons

\begin{tabular}{|c|c|c|c|}
\hline & \multirow{2}{*}{ Morph } & \multicolumn{2}{|c|}{$\begin{array}{l}\text { Rate of predation (in number) } \\
\text { per day }\end{array}$} \\
\hline & & S. annulatum & S. rusticum \\
\hline \multirow{6}{*}{ 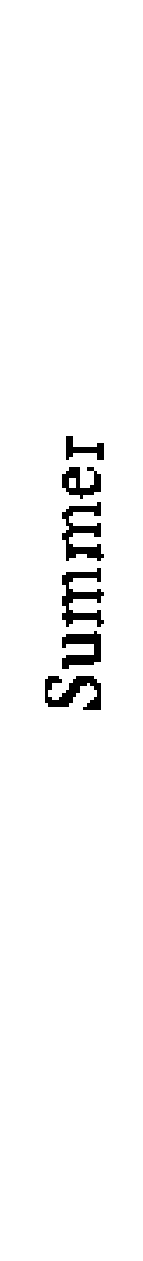 } & Instar I & $\begin{array}{c}6-41 \\
(16.10 \pm 1.05)\end{array}$ & $\begin{array}{c}5-15 \\
(9.92 \pm 0.41)\end{array}$ \\
\hline & II & $\begin{array}{c}845 \\
(19.28 \pm 1.22)\end{array}$ & $\begin{array}{c}6-19 \\
(11.74 \pm 0.46)\end{array}$ \\
\hline & III & $\begin{array}{c}8-50 \\
(20.83 \pm 1.34)\end{array}$ & $\begin{array}{c}7-32 \\
(13.55 \pm 0.79)\end{array}$ \\
\hline & IV & $\begin{array}{c}10-57 \\
(23.01 \pm 1.43)\end{array}$ & $\begin{array}{c}7-33 \\
(14.49 \pm 0.88)\end{array}$ \\
\hline & $\mathrm{V}$ & $\begin{array}{c}13-62 \\
(25.69 \pm 1.55)\end{array}$ & $\begin{array}{c}8-37 \\
(17.24 \pm 0.97)\end{array}$ \\
\hline & Adult & $\begin{array}{c}11-61 \\
(25.22 \pm 1.65)\end{array}$ & $\begin{array}{c}8-35 \\
(16.84 \pm 0.91)\end{array}$ \\
\hline \multirow{6}{*}{$\begin{array}{l}\tilde{E} \\
0 \\
0 \\
\\
\\
\Sigma\end{array}$} & Instar I & $\begin{array}{c}4-14 \\
(8.65 \pm 0.36)\end{array}$ & $\begin{array}{c}3-15 \\
(8.32 \pm 0.37)\end{array}$ \\
\hline & II & $\begin{array}{c}5-34 \\
(11.74 \pm 0.86)\end{array}$ & $\begin{array}{c}5 \cdot 15 \\
(9.66 \pm 0.39)\end{array}$ \\
\hline & III & $\begin{array}{c}542 \\
(14.46 \pm 1.15)\end{array}$ & $\begin{array}{c}5-17 \\
(9.98 \pm 0.41)\end{array}$ \\
\hline & IV & $\begin{array}{c}549 \\
(16.70 \pm 1.40)\end{array}$ & $\begin{array}{c}7-19 \\
(11.00 \pm 0.44)\end{array}$ \\
\hline & V & $\begin{array}{c}6-51 \\
(19.10 \pm 1.45)\end{array}$ & $\begin{array}{c}7-29 \\
(13.07 \pm 0.72)\end{array}$ \\
\hline & Adult & $\begin{array}{c}3-50 \\
(18.54 \pm 1.73)\end{array}$ & $\begin{array}{c}7-23 \\
(12.45 \pm 0.58)\end{array}$ \\
\hline \multirow{6}{*}{ 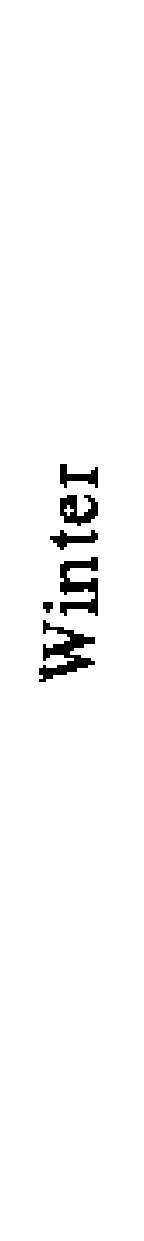 } & Instar I & $\begin{array}{c}1-7 \\
(3.69 \pm 0.20)\end{array}$ & $\begin{array}{c}1-6 \\
(3.33 \pm 0.17)\end{array}$ \\
\hline & II & $\begin{array}{c}2-11 \\
(4.92 \pm 0.28)\end{array}$ & $\begin{array}{c}1-7 \\
(3.67 \pm 0.22)\end{array}$ \\
\hline & III & $\begin{array}{c}2-12 \\
(6.13 \pm 0.33)\end{array}$ & $\begin{array}{c}1-9 \\
(3.96 \pm 0.26)\end{array}$ \\
\hline & IV & $\begin{array}{c}2-13 \\
(6.79 \pm 0.36)\end{array}$ & $\begin{array}{c}2-10 \\
(5.18 \pm 0.26)\end{array}$ \\
\hline & V & $\begin{array}{c}3-14 \\
(8.64 \pm 0.39)\end{array}$ & $\begin{array}{c}2-12 \\
(6.83 \pm 0.39)\end{array}$ \\
\hline & Adult & $\begin{array}{c}1-21 \\
(7.18 \pm 0.57)\end{array}$ & $\left(\begin{array}{c}1-11 \\
(5.20 \pm 0.38)\end{array}\right.$ \\
\hline
\end{tabular}

significant effect on predation (Table V). The variations noted in the rates of predation by these waterbugs in respect to temperatures are not statistically significant. The size of prey individuals has biggest effect so far rate of predation of $S$. annulatum is concerned (Table VI). But such an effect in $S$. rusticum is insignificant 
TABLE V

Analysis of variance (ANOVA) showing the effect of the age of the waterbugs Sphaerodema annulatum and $S$. rusticum on the rate of predation on the snails Lymnaea (Radix) luteola

\begin{tabular}{lrrrr}
\hline $\begin{array}{l}\text { Source of } \\
\text { variation }\end{array}$ & df & \multicolumn{1}{c}{ SS } & \multicolumn{1}{c}{ MS } & \multicolumn{1}{c}{ F } \\
\hline Species & 1 & 38109.34 & 38109.34 & $1467.02^{a}$ \\
Age & 2 & 2336.75 & 1168.37 & $44.98^{a}$ \\
Species X Age & 2 & 926.24 & 463.12 & $17.83^{a}$ \\
Error & 511 & 13274.40 & 25.98 & \\
\hline Total & 516 & 54646.73 & & \\
\hline
\end{tabular}

a. significant at $5 \%$ level

TABLE VI

Analysis of variance showing the impact of preysize on the rate of predation of the waterbugs Sphaerodema annulatum

\begin{tabular}{lcccc}
\hline $\begin{array}{l}\text { Source of } \\
\text { variation }\end{array}$ & df & SS & MS & F \\
\hline Species & 1 & 787.5 & 787.5 & $66.886^{a}$ \\
Size & 3 & 4963.857 & 1654.6191 & $139.827^{a}$ \\
Species X Size & 3 & 35.5 & 11.833 & $1.005^{b}$ \\
Error & 48 & 565.143 & 11.774 & - \\
\hline Total & 55 & 6352.0 & - & - \\
\hline
\end{tabular}

$a$ : significant at $5 \%$ level; $b$ : insignificant

(Table VII). Though both the waterbug species consumed $L$. (R.) luteola of different size groups $S$. annulatum has a significant effect on predation rate. Interestingly, the species $S$. rusticum and the size of $L$. (R.) luteola interact to have a significant effect. On a fixed density of prey individuals each waterbug species has a significant effect on the rate of predation. The increased predator density from 5 to 20 , as well as the interaction of the predator species and the predator density have no effect on predation rate. To justify the validity of the recorded threshold density level of the prey-snails $\chi^{2}$ test was applied. Such a phenomenon is justified from the difference noted in $\chi^{2}$ calculated $=1141.12$ and $\chi^{2}$ observed $=18.48$ values. Moreover, it is evident that the time (days) period has a significant effect on the rate of predation in $S$. annulatum while the prey density level has a significant effect on the rate of predation in both the waterbug species. Though the height of water column has no role in regulating the predation rate the surface area of the waterbody has a significant effect on the same (Table VIII).
Considering surface area as $x$ and predation rate as $y$ an exponential model was fitted with the observed data to determine the desired accuracy. The linear and the first degree exponential models for both the species were:

Linear: $y=46.725619-0.0082972 x$

Exponential: $y=48.5414(0.9997577) x$

while the second degree exponential model for $S$. annulatum

$y=25.38769 x \exp \left[0.000000061 x(x-3523.41)^{2}\right]$

S. rusticum

$y=13.3245 x \exp \left[0.00000013 x(-2924.49)^{2}\right]$.

\section{TABLE VII}

Analysis of variance showing the impact of preysize on the rate of predation of the waterbugs Sphaerodema rusticum

\begin{tabular}{lrccc}
\hline $\begin{array}{l}\text { Source of } \\
\text { variation }\end{array}$ & df & SS & MS & F \\
\hline Species & 1 & 10.006 & 10.006 & $2.364^{b}$ \\
Size & 3 & 178.827 & 59.609 & $0.859^{b}$ \\
Species X Size & 3 & 208.065 & 69.355 & $16.39^{a}$ \\
Error & 160 & 667.0476 & 4.2315 & - \\
\hline Total & 167 & 1073.946 & & \\
\hline
\end{tabular}

$a$ : significant at $5 \%$ level; $b$ : insignificant

\section{TABLE VIII}

Analysis of variance (ANOVA) showing the effect of the surface area on the rate of predation of the waterbugs Sphaerodema annulatum and S. rusticum

\begin{tabular}{lrrrc}
\hline $\begin{array}{l}\text { Source of } \\
\text { variation }\end{array}$ & df & SS & MS & F \\
\hline $\begin{array}{l}\text { Due to species } \\
\text { Due to surface } \\
\text { area }\end{array}$ & 1 & 2392.5952 & 2392.5952 & $36.894^{a}$ \\
$\begin{array}{l}\text { Species X } \\
\text { Surface area }\end{array}$ & 2 & 1414.9047 & 707.452 & $140.818^{a}$ \\
Error & 2 & 10.0477 & 5.0238 & $<1^{b}$ \\
\hline Total & 41 & 61534.5714 & 64.8492 & - \\
\hline
\end{tabular}

$a$ : significant at $5 \%$ level; $b$ : insignificant

From the above fittings it is clear that in $S$. annulatum the mean minimum consumption rate (five individuals together) would be 25.38 in a surface area $3523 \mathrm{~cm}^{2}$ while in $S$. rusticum the minimum average predation rate would be 13.32 in the surface area $2924.49 \mathrm{~cm}^{2}$. In all probabilities there exists a significant effect of the season on the rate of predation of $S$. annulatum and $S$. rusticum. The results of ANOVA (Table 
IX) studies clearly indicate that the season has the biggest effect while predator species, instar stages of the predator species, the interaction of predator species and the season, the predator species and its instar stages, the season, the instar stages and the predator species, and the instar stages and season have significant effect on the rate of predation of $S$. annulatum and $S$. rusticum.

\section{TABLE IX}

Analysis of variance (ANOVA) showing the impact of seasons on the rate of predation of the waterbugs Sphaerodema annulatum and S. rusticum

\begin{tabular}{lrrrr}
\hline $\begin{array}{l}\text { Source of } \\
\text { vatiation }\end{array}$ & df & \multicolumn{1}{c}{ SS } & MS & \multicolumn{1}{c}{ F } \\
\hline Species (A) & 1 & 475.549 & 475.549 & $185.417^{a}$ \\
Season (B) & 2 & 5061.598 & 2530.799 & $986.762^{a}$ \\
Instar (C) & 4 & 945.354 & 236.388 & $92.148^{a}$ \\
AB & 2 & 594.995 & 297.497 & $115.994^{a}$ \\
AC & 4 & 209.208 & 52.302 & $20.392^{a}$ \\
BC & 8 & 142.179 & 17.772 & $6.929^{a}$ \\
ABC & 8 & 1778.106 & 222.263 & $86.661^{a}$ \\
Error & 180 & 461.655 & 2.5647 & - \\
\hline Total & 209 & 9668.645 & \multicolumn{2}{c}{-} \\
\hline
\end{tabular}

$a$ : significant at $5 \%$ level

\section{DISCUSSION}

From the results it is evident that the rate of predation in $S$. annulatum and $S$. rusticum is greatly influenced by the age and/or size and density of predators and prey animals; by the temperature and surface area of water-body, and by the seasons of the year. It appears that an individual $S$. annulatum and $S$. rusticum consumed, on an average 7.2, 5.2 and 2.9 , and 2.2, 1.7 and $1.5 L$. (R.) luteola per day respectively at pre-reproductive, reproductive and post-reproductive ages. The estimated average total number of consumption is going to be 1601.18 and 488.24 during the period of 303.2 and 284 days of average total life span of $S$. annulatum and $S$. rusticum respectively. It seems that the rate of predation is age dependent, perhaps in respect to nutritional requirement of the waterbug species concerned. This can also be explained from the fact of gradually higher rate of consumption by the larvae as they moved from first to fifth instar stages.

The increased consumption rate by the larvae of same stage and age with the rise of temperature from $20^{\circ} \mathrm{C}$ to $30^{\circ} \mathrm{C}$, at an interval of $5^{\circ} \mathrm{C}$ may be accounted from the fact of higher rate of digestion as has been discussed by
Schmidt-Nielsen (1973). Since, at higher temperatures, more energy is needed to maintain respiration as per physiological stage of the individuals concerned, additional snail consumption is a must at each higher temperature grade. The impact of temperature on consumption rate is well evident from the fact of consumption rates noted at $25^{\circ} \mathrm{C}$ and $30^{\circ} \mathrm{C}$ constant temperatures, and room temperatures (mean minimum $22.5^{\circ} \mathrm{C}$ and mean maximum $26.5^{\circ} \mathrm{C}$ ). This indicates that temperature determines the rate of consumption in animals. This could further be substantiated from the fact of highest and lowest consumption rates noted during summer $\left(27-32.5^{\circ} \mathrm{C}\right)$ and winter $\left(17.5-20.5^{\circ} \mathrm{C}\right)$ respectively in these waterbugs.

Prey size has an impact on the predator's performance. Predators prefer certain sizes of the prey and are known to consume them in a higher proportion as they are relatively abundant in nature (Peckarsky 1982). Lethocerus americanus is reported to capture prey as large as the lethocerine itself (Nieser 1975). In the aquatic hemipterans prey size selection is governed by the hit distance and strike efficiency (Cloarec 1980), time spent to capture the prey (Thompson 1978, Evans 1982) and the potency of the bug in turn depend on its foreleg movements (Cloarec 1983). Predation rate has been reported to decrease with the increasing prey size (Venkatesan \& Cloarec 1988). The same phenomenon has also been noted in $S$. annulatum and $S$. rusticum in the present studies. The consumption of higher number of prey individuals of lower size group not only related with the fact of easy over-powering of the prey individual but also to fulfil the need of required food. Since small prey snail individuals contain less amount of food a waterbug had to consume the snails as many as six individuals of smallest size group per day contrast to an average consumption rate of 1.5 individuals belonged to largest size group. As the waterbugs consumed higher number of snail individuals belonged to larger size groups while prey snails of all the sizes were supplied together, it is most likely that the bugs prefer to attack the prey individuals of maximum size to be captured by them. This sort of prey selection enables the predator to have the require amount food by capturing less number of larger prey individuals. A similar phenomenon has also been noted in Ilyocoris cimicoides by Venkatesan and Cloarec (1988). This suggests that the waterbugs are also conscious to avoid unnecessary troubles in capturing large number of prey individuals. The present findings support the idea of Glasser (1978) that the predators utilise the resource 
selectively when prey species are abundant in nature.

Efficiency of predation is mostly density dependent (Odum 1971). It is also well evident from the fact of gradually higher rate of predation by the ten waterbugs with the gradual increase of prey density from 100 to 1100 for $S$. annulatum and from 100 to 700 for $S$. nisticum. After this, prey density had no role on the rate of predation of waterbugs. This means that prey density above the threshold density level never invites competition among the predators for prey catching. A similar phenomenon has also been noted by Sjostrom (1983) in Dinocras cephalotes and by Cloarec (1983).

Both the waterbugs and snails are surface dwellers. The water surface not only provides accommodation for these animals but also determines the rate of predation. This is well evident from the fact of increased predation rate in $S$. annulatum and $S$. misticum under increased surface area. On the contrary, no change in predation rate, in waterbodies having different depths is expected, and justificd from the results obtained.

Predators may respond to an increase of prey 'functionally', by an increase in number of prey consumed per individual predator 'numerically', by an increase in number of predators, or by a combination of the two (Solomon 1949, Holling 1959). This has already been observed in the present study on $S$. anmulatum and $S$. rusticum. Though in nature, the predators have the chance to accept different kinds of prey individuals, the waterbugs mostly prefer the snails $L$. (R.) Iuteola over other (Raut \& Saha 1989). It is evident that an aduit $S$. annulatum in its average life span of 303 days (from the date of attainment of adult stage i.c., zero-day old, to the date of death) consumed an average total of 1601 Lymnaea (Radix) luteola. An individual of $S$. misticum in its average life span of 284 days (from zero-day old adult stage to the date of death) consumed on the average 488 Lymnaea (Radix) lateola. However, the total kill of Lymnaea (Radix) luteola by an individual of waterbug of any species would be higher. Because, the bugs had to overcome the five larval stages to be metamorphosed into the adult stage. Since a larva belongs to first, second, third, fourth and fifth instar nymphs of $S$. annulatum consumed, on the average $2.3,2.5,2.7,3.0$ and 3.5 Lymnaea (Radix) luteola daily and the duration of first, second, third, fourth and fifth instar stages were $6.2,5.3,8.0,10.1$ and 13.6 days respectively at room temperatures $\left(22.5-26.5^{\circ} \mathrm{C}\right)$, it is estimated that a total of 127 Lymnaea (Radix) huteola are consumed by a larva prior to attainment of adult stage. Now, it is clear that, an individual $S$. annulatum consumed a total of 1728 Lymnaea (Radix) luteola in its entire life span i.e., from the date of hatching to the date of death. Under similar conditions a larva belongs to $S$. nusticum consumed 1.6, 1.7, 1.9, 2.0 and 2.4 Lymnaea (Radix) luteola per day at first, second, third, fourth and fifth instar stages respectively. Since the duration of instar stages was 8.9, 6.9, 7.04, 7.93 and 17.16 days respectively, an individual belongs to $S$. rusticum consumed an average total of 585 Lymnaea (Radix) luteola during its entire life span i.e. from the date of hatching to death.

It is observed that the larvae of Limnogeton fieberi consumed 126 individuals of Biomphalaria glabrata (Say) and Physella acuta. Taking total consumption of both the larvae and adults Voelker $(1966,1968)$ estimated that in the life span of a female and male, $L$. fieberi can destroy as many as 1800 and 670 snail individuals respectively. Raut and Saha (1989) reported that one generation of $S$. annulatum can consume three generations of Lymnaea (Radix) luteola, Lymnaea (Radix) acuminata and Gyraulus convexiuxculus. In the present study an individual belongs to $S$. anntilatum consumed a total of 1728 Lymnaea (Radix) luteola and an individual belongs to $S$. rusticum consumed a total of 585 Lymnaea (Radix) luteola. These findings confering the potentiality of waterbugs in reducing the host snail population of the locality concerned. Since the waterbugs, $S$. annulatum and $S$. rusticum have shown wide range of variations in consumption rate of the snails Lymnaea (Radix) luteola in respect to seasons, studies on the rates of recruitment of Lymnaca (Radix) luteola and the waterbugs $S$. annulatum and $S$. rusticum are to be conducted with great care with a view to determine the most effective predator-prey ratio. It is sure that the vector snail population could drastically be reduced if the predaceous waterbugs are employed in that effective ratio after determining the same following experimental studies.

\section{ACKNOWLEDGEMENTS}

To the Head, Department of Zoology, University of Calcuta, for providing necessary facilities and to Mr TK Ghora, Department of Statistics, Presidency College. Calcutta for assistance in statistical analysis of the data.

\section{REFERENCES}

Abcbe F 1991. Laboratory assessment of the molluscicidal effect of B-2 (Sodium, 2,5, dichloro-4bromophenol) against five ethiopian freshwater snail species. I Med \& Appl Malacol 3: 97-100.

Bay EC. Berg CO, Chapman HC, Lenger EF 1976. Bio- 
logical control of medical and veterinary pests, $p$. 457-479. In CB Huffacker, Theory and practice of biological control. Academic Press, New York, San Francisco, London.

Berg CO 1953. Sciomyzid larvae (Diptera) that feed on snail. J Parasitol 39: 629-636.

Berg CO 1964. Snail control in trematode diseases: the possible value of sciomyzid larvac, snail-killing Diptera, p. 259-309. In B Dawes, Advances in parasitology. Vol. 2. Academic Press, New York.

Chatterjee KID 1952. Iuman parasites and parasitic diseases. The World Press Lid., Calcutta, vi +766 pp.

Chernin E, Michelson EH, Augustine DL 1956. Studies on the biological control of Schistosome-bearing snails. I. The control of Australorbis glabratus by the snail Marisa cornuarietis under laboratory conditions. Amer J Trop Med Hyg 5: 297-307.

Chu KY 1978. Trials of ecological and chemical measures for the control of Schistosoma haematobium in a Volta Lake village. Bull WIIO 56: 313-322.

Cloarec $A$ 1980. Post-moult behaviour in the Water Stick insect Ranatra linearis. Behaviour 73: 304-324.

Cloarec A 1983. Variations de la structure de la patte revissense de Ranatra linearis L. (Heteroptera: Nepidae) aucours due development larvaire 1. Morphogense. Bull Soc Scien Bert 48: 161-178.

Debach P 1974. Biological control by Natural enemies. Cambridge University Press, London and New York, $\mathrm{xi}+323 \mathrm{pp}$

Demian ISS, Lutfy RG 1966. Factors affecting the predation of Marisa comuarietis on Bulinus (B.) truncatus, Biomphalaria alenandrins and Lymnaea callandi. Oikos 17: 212-230.

Deschiens MR, Lamy L 1955. Prehension et ingestion des mollusques vecteurs des billharzioses par les ecrevisses du genre cambarus. Bull Soc Pathol Exot 48: 203-207.

Deschiens R. Dechance M. Vermeil C 1955. Prehension et ingestion des mollusques vecteurs des bilharzioses раг les ecrevisses du genre Cambarus. Bull Soc Pathol Exot 48: 201-203.

Evans EW 1982. Feeding specialization in predatory insects: Hunting and attack behaviour of two stinkbug species (Hemiptera: Pentatomidae). The Am Midl Natur 108: $96-104$

Glasser JW 1978. The effect of predation on prey resource utilization. Ecology 59: 724-732.

Godan. I) 1983. Pest slugs and snails. Springer-Verlag. Berlin, Heidelberg. New York. vi $\div 445 \mathrm{pp}$.

Goon AM, Gupta MK. Dasgupta B 1976. Fundamentals of Statistics. Vol. 2. The World Press Ltd., Calcutta, $\mathrm{xiii}+431 \mathrm{pp}$.

Hairston NG, Wuzzinger KH, Burch JB 1975. Non-chemical methods of snail control. WHOVBC 75.573, WHO/SCHISTO/75.40, 1-30.

Holling CS 1959. The components of prodation as revealed by a study of small mammal predation of the European pine-saw 17y. Canadian Ent 91: 293-320.

Jobin WR. Ferguson FF, Palmer JR 1970. Control of Schistosomiasis in Guayoma and Arroyo, Puerto Rico. Bull WHO 42: 151-156.

Levine ND 1970. Integrated control of snails. Amer Zoologist 10: $579-582$.

Lo C-T 1967. The inhibiting action of ostracods on snail cultures. Trans Amer Microsc Soc 86: 402-405.

Maillard Y-P 1971. La malacophagic dans le genre
Hydrophilus Geoffroy (Ins. Colepteres. Hydrophilidac). Son interet dans le controle natural des hotes intermediares d'helminthiases. CR Acad $S_{C l}$ (Paris) 272: 2235-2238.

Malek EA, Cheng TC 1974. Medical and Economic Malacology. Academic Press, New York, London, 408 pp.

Nieser N 1975. Studies on the fauna of Suriname and other Guyanas No. 59. The Waterbugs (Heteroptera: Nepomorpha) of the Guyana region. Ulig Natuur Wet Studiekring Suriname, Ned Antillen, 81: 50-87.

Odum EP 1971. Fundamentals of ecology, 3rd ed. W.B. Saunders Company, Philadelphia, xiv +574 pp.

Peckarsky BL 1982. Aquatic insect predator-prey relations. Bioscience 32: 261-266.

Pielou EC 1977. Mathematical ecology. John Wiley and Sons, New York, xii +386 pp.

Radke MG. Ritchic LS, Ferguson FF 1961. Demonstrated control of Australorbis glabratus by Marisa cormuarietis under field conditions in Puerto Rico. Am J Trop Med Hyg 10: 370.

Raut SK 1981. Population interaclion among freshwater snails. Proc Symp Ecol Popul Zool Sur, India, Pt. 2 . 163-173.

Raut SK 1982. Disease transmitting snails. I. Population studies of Lymnaea luteola forma typica. Thesis for admission to PRS of Calcutta University, Calcutta.

Raut, SK 1986. Disease transmitting snails. II. Population studies of Indoplanorbis exustus (Deshayes). First year's PRS Thesis of Calculta University, Calcutta.

Raut SK 1988. Biological assessment of predacious waterbugs in the control potential of vector prey snails. Bicovas 2: 145-155.

Raut SK 1989. Disease transmitting snails. III. Population studies of Gyraulus convexiusculus (Ihitton). Second year's PRS Thesis of Calcutta University, Calcutta.

Raut SK, Ghosh U 1985. Egg capsules of some freshwater vector snails. Emiron \& Ecol 3: 214-217.

Raut SK. Nandi NC: 1985. The Leech Glossiphonia weberi in the control of the host-snail, Lymnaca lateola a predator - prey interaction study. Environ \& Ecol 3: $21-24$.

Raut SK, Saha TC 1988. Influence of temperature on predation of the waterbug Sphatrodema annulatum on the vector snail Lymnaea lateola. Bicovas 2: 85 . 98.

Raut SK, Saha TC 1989. The role of waterbug Sphaerodema anmulatum in the control of disease transmitting snails. J Med \& Appl Malacol 1: 97-106.

Raut SK, Saha TC, Mukhopadhyay B 1988. Predacious waterbugs in the control of vectors snails. Bicov'as $I$ : $175-185$.

Ruiz-Tiben E, Palmer JR, Ferguson F 1969. Biological control of Biomphalaria glabrata by Marisa cormuarietis in irrigation ponds in Puerto Rico. Bull WHO 41: 329-333.

Saha TC, Raut SK 1991. Bioecology of the water-bug Sphaerodema annulatum Fabricius (Heteroptera: Belostomatidae) Arch Hydrobiol 124: 239-253.

Schmidt-Niclsen K 1973. Animal Physiology. PrenticeIall of India Pvt Ltd, New Delhi, $x+145$ pp.

Sjostrom P 1983. Hunting, spacing and antipredatory behaviour in nymphs of Dinocras cephalotes (Plecoptera). PhD Thesis, Univ. Lund., Lund-Sweden, 67 pp. 
Solomon ME 1949. The natural control of animal populations. J An Ecol 18: 1-35.

Somasundarao G 1963. A preliminary note on the biological control of freshwater snails by aquatic insects. Ind Vet J 40: 50.

Thomas JD 1973. Schistosomiasis and the control of molluscan hosts of human schistosomes. Parasitol 11: $307-394$.

Thonpson DJ 1978. Prey-size selection by larvae of the Demselfly, Ischmura elegans (Odonata). J Anim Ecol 47: 769.785 .

Venkatesan P. Cloarec A 1988. Density dependent prey selection in waterbug. $A q$ Ins $10: 105-106$.
Voelker J 1966. Wasserwanzen als obligatorische Schnecken fresser im Nildelta (Limnogeton fieberi Mayr, Belostomatidae, Hemiptera). Z Tropenmed Parasitol 17: 155-165.

Voelker J 1968. Untersuchungen zur Ernahrung, Fortpflazungs biologie and Entwicklung von Limnogeton fieberi Mayr. (Belostomatidae, Hemiptera) als Beitrag Zur Kenntnis von naturlichen Feinden tropischer subwasserschnecken. Entom Mitt Zool Staatsinst Zool Mus Hamburg 3: 1-24.

Wright CA 1968. Some views on biological control of trematode disease. Trans $\mathrm{R}$ Soc Trop Med Hyg 62: 320-324. 